\title{
Production of Citric Acid from Corncobs with Its Biological Evaluation
}

\author{
Ahmed Ashour',2, Saleh El-Sharkawy2,3, Mohamed Amer², Amani Marzouk2, Ahmed Zaki2, \\ Asuka Kishikawa', Momiji Ohzono", Ryuichiro Kondo1, Kuniyoshi Shimizu1* \\ ${ }^{1}$ Department of Agro-Environmental Sciences, Faculty of Agriculture, Kyushu University, Fukuoka, Japan \\ ${ }^{2}$ Department of Pharmacognosy, Faculty of Pharmacy, Mansoura University, Mansoura, Egypt \\ ${ }^{3}$ Department of Pharmacognosy, Faculty of Pharmacy, Delta University for Science and Technology, Mansoura, \\ Egypt \\ ${ }^{4}$ Zenshin Incorporated, Chikushino City, Japan \\ Email: ${ }^{*}$ shimizu@agr.kyushu-u.ac.jp
}

Received 2 April 2014; revised 1 May 2014; accepted 8 May 2014

Copyright (C) 2014 by authors and Scientific Research Publishing Inc.

This work is licensed under the Creative Commons Attribution International License (CC BY).

http://creativecommons.org/licenses/by/4.0/

c) (i) Open Access

\begin{abstract}
Corncobs could serve as a substrate for citric acid production using solid state fermentation technique. The culture optimization concerning substrate concentration, culture duration, $\mathrm{pH}$, temperature and substrate hydrolysis was carried out for maximum productivity of citric acid. Under the optimized conditions, $48.4 \mathrm{~g}$ of citric acid was produced from $1 \mathrm{~kg}$ dry corncobs. Biological evaluation was carried out for citric acid such as melanin synthesis inhibitory, anti-allergy, anti-bacterial, and hyaluronic acid production activities. The results showed that citric acid has potent melanin inhibitory activity, good inhibition for $\beta$-hexosaminidase release and potent stimulatory effect for the production of hyaluronic acid. These activities (melanin synthesis inhibitory, anti-allergy and hyaluronic acid productive activities) of citric acid have been reported for the first time.
\end{abstract}

\section{Keywords}

Corncobs, Citric Acid, Fermentation, Melanin, Allergy, Hyaluronic Acid

\section{Introduction}

The vast development in industry, agriculture and the human civilization resulted in intensive production of a huge amount of agro-industrial wastes. In Egypt, a large amount of corncobs are produced every year and no effective methods are being used for its utilization. The accumulation of this waste causes a serious environmental

*Corresponding author. 
disposal problem represented in the fermentation of such wastes, their degradation products, psychological hazards and other related health problems [1] which increase the burden on the national economy.

Corncobs are an important by-product of the sweet corn processing industry in Egypt, where they represent about $15 \%$ of total corn production.

The amount of corncobs produced was estimated to be about 54,424 tons in 2008 (according to data obtained from the Directorate of Agriculture, Egypt). Worldwide, these large amounts are either used as animal feed or are returned to the harvested field [2].

Corncobs are rich in cellulose and hemicellulose that has been used as a cheap source of raw material for production of soluble sugars and other value-added products by enzymatic and microbial fermentation processes [3].

Citric acid is one of the world's largest tonnages of fermentation products. It has a wide variety of application due to high solubility, low toxicity and palatability in the food and beverage industry (70\%), in pharmaceuticals (12\%) and in other industrial applications (18\%) [4]. It is produced commercially by submerged fermentation of sucrose or molasses based medium [5]. Recently, there have been an increasing number of reports on the use of solid state fermentation (SSF) processes as an alternative to submerged fermentation [6]. This is because of lower energy requirements, higher product yields, little risk of bacterial contamination, less waste water generation and environmental concerns concerning the disposal of solid waste [7].

\section{Material and Methods}

\subsection{Agro-Waste Material}

Corncobs were obtained on August 2008 by Prof. Dr. Ahmed Nader, Agronomy Department, Faculty of Agriculture, Mansoura University, from plants grown in a field at the university campus.

Corncobs type was identified as Zea mays hybrid individual 3080. They were milled to a particle size of 1.25 $\mu \mathrm{m}$. A voucher specimen (No. 1536) was deposited at the Department of Pharmacognosy, Faculty of Pharmacy, Mansoura University.

\subsection{Biotransformation}

\subsubsection{Microorganisms}

Aspergillus niger ATCC 10549, Aspergillus alliaceus UI 315, Aspergillus flavipes ATCC 11013, Aspergillus flavipes ATCC 16795, Congronella butleri ATCC 22822, Rhodotorula rubra ATCC 20129, Fusarium oxysporum ATCC 7601 and Debaryomyces polymorphus ATCC 20280.

The strains were maintained on potato dextrose agar (PDA) slants at $4^{\circ} \mathrm{C}$ and sub-cultured at intervals from 1 to 2 months [8].

\subsubsection{Methods}

Experiments were conducted in $250 \mathrm{~mL}$ flasks, each containing 10 g powdered corncobs with $50 \mathrm{~mL}$ water adjusted to $\mathrm{pH}$ 7.4.

All flasks containing corncobs were sterilized at $121^{\circ} \mathrm{C}$ for $15 \mathrm{~min}$, cooled and inoculated with test organisms, all experiments were done in duplicates.

All flasks were incubated at $30^{\circ} \mathrm{C}$ and the production of acidic conditions was monitored by means of $\mathrm{pH}$ paper where a sample was pipetted every day for 30 days, the flask which converted the color of the paper to the red color indicated acidic medium produced by the microorganism in this flask. The results of this screening are shown in Table 1.

The liquid medium, which showed acidic condition, was further subjected to HPLC using reversed column C18 to determine the type of acid produced by comparing the retention time of acid produced with the library of retention times.

Citric acid was determined by HPLC (series 200 HPLC, Perkin Elmer, USA) under the following conditions: RP-18 column (inertsil ODS-3, Shimadzu $5 \mu \mathrm{m}, 25 \mathrm{~cm} \times 0.5 \mathrm{~cm}$ i.d.).

Separation was achieved using phosphate buffer, $\mathrm{pH} 2.1$ as mobile phase at flow rate $1 \mathrm{~mL} / \mathrm{min}$ for $30 \mathrm{~min}$. Eluting peaks were monitored by UV detector at $210 \mathrm{~nm}$.

It was concluded that $A$. niger ATCC 10549 produce citric and oxalic acids while all other tested organisms produced only oxalic acid so A. niger ATCC 10549 was selected for further study. 
Table 1. Results of screening of different microorganisms for production of acidic medium from corncobs*.

\begin{tabular}{cc}
\hline Microorganism & Result \\
\hline Aspergillus niger ATCC 10549 & + \\
Aspergillus alliaceus UI 315 & - \\
Aspergillus flavipes ATCC 11013 & - \\
Aspergillus flavipes ATCC 16795 & - \\
Congronella butleri ATCC 22822 & + \\
Rhodotorula rubra ATCC 20129 & + \\
Fusarium oxysporum ATCC 7601 & + \\
Debaryomyces polymorphus ATCC 20280 & + \\
\hline
\end{tabular}

*+: acidic medium, --: non acidic medium.

\subsubsection{Culture Optimization}

1) Optimization of concentration of the spores for citric acid production. Concentration of the spores of the highest citric acid producing organism (A. niger ATCC 10549) was adjusted to $9.6 \times 10^{6}$ spores/mL and used in each experiment.

2) Culture incubation period: $6,8,10,12,14$ and 16 days.

3) Substrates concentration: conical flasks $(250 \mathrm{~mL})$ containing $50 \mathrm{~mL}$ of water supplemented with 3, 6, 9, 12, 15, 20, 30 g corncobs to obtain a substrate concentration $6 \%, 12 \%, 18 \%, 24 \%, 30 \%, 40 \%$ and $60 \%$, respectively.

4) Initial $\mathrm{pH}$ values of 3, 5, 5.5, 6, 6.5, 7 and 8 were adjusted by $1 \mathrm{~N} \mathrm{HCl}$ and $1 \mathrm{~N} \mathrm{NaOH}$.

5) Temperature: $5^{\circ} \mathrm{C}, 15^{\circ} \mathrm{C}, 24^{\circ} \mathrm{C}, 30^{\circ} \mathrm{C}, 37^{\circ} \mathrm{C}$ and $42^{\circ} \mathrm{C}$.

Quantitative analysis of citric acid was done conducting the acetic anhydride and pyridine method of Marier and Boulet [9]. It should be noted that no other organic acid such as oxalic acid was interfering with quantitative data of citric acid.

\subsubsection{Standard Curve of Citric Acid [9]}

Appropriate dilutions (50 - $300 \mu \mathrm{g} / \mathrm{mL}$ ) were made from the stock solution of citric acid $(5 \mathrm{mg} / \mathrm{mL})$. One millitre of each dilution followed by $1.30 \mathrm{~mL}$ of pyridine was added into individual test tubes and swirled. Acetic anhydride $(5.70 \mathrm{~mL})$ was then added into each tube. These samples were placed in a water bath at $32^{\circ} \mathrm{C}$ for $30 \mathrm{~min}$. A blank was run in parallel replacing $1 \mathrm{~mL}$ of the sample with distilled water. The intensity of yellow color obtained was measured at $405 \mathrm{~nm}$. A calibration curve was drawn taking the citric acid concentration at $\mathrm{X}$-axis and optical density at Y-axis.

\subsubsection{Estimation of Citric Acid in the Culture Filtrate}

The diluted culture filtrate $(1 \mathrm{~mL})$ was treated as mentioned above, blank test was carried out parallel with the sample using $1 \mathrm{~mL}$ distilled water instead of culture filtrate.

\subsection{B16 Melanoma Cell Line Assay}

This assay was performed as described previously [10]. The cells were placed in two 24-well plastic culture plates (one plate for determining melanin and the other for cell viability) at a density of $1 \times 10^{5}$ cells/well and incubated for $24 \mathrm{~h}$ in media prior to being treated with the samples. After $24 \mathrm{~h}$, the media were replaced with $998 \mu \mathrm{L}$ of fresh media and $2 \mu \mathrm{L}$ of the test sample at concentrations of $6.25,12.5,25,50,100$, and $200 \mathrm{mg} / \mathrm{mL}$ $(n=3)$. At the same time, a negative control ( $2 \mu \mathrm{L}$ DMSO) and a positive control $(2 \mu \mathrm{L}$ DMSO with arbutin at a concentration of $50 \mathrm{mg} / \mathrm{mL}$ ) were tested. The cells were incubated for an additional $48 \mathrm{~h}$, and then the medium was replaced with fresh medium containing each sample. After $24 \mathrm{~h}$, the remaining adherent cells were assayed. To determine the melanin content (for one plate) after removing the medium and washing the cells with PBS, the cell pellet was dissolved in $1.0 \mathrm{~mL}$ of $1 \mathrm{~N} \mathrm{NaOH}$. After being kept in the dark overnight, the crude cell extracts were assayed by using a microplate reader at $405 \mathrm{~nm}$ to determine the melanin content. The results from 
the cells treated with the test samples were analyzed as a percentage of the results from the control culture. Cell viability was determined by an MTT assay, which provides a quantitative measure of the number of viable cells by determining the amount of formazan crystals produced by metabolic activity in treated versus control cells. For the other well plate, $50 \mu \mathrm{L}$ of MTT reagent in PBS $(5 \mathrm{mg} / \mathrm{mL})$ was added to each well. The plates were incubated in a humidified atmosphere of $5 \%$ of $\mathrm{CO}_{2}$ at $37^{\circ} \mathrm{C}$ for $4 \mathrm{~h}$. After the medium was removed, $1.0 \mathrm{~mL}$ isopropyl alcohol (containing $0.04 \mathrm{~N} \mathrm{HCl}$ ) was added, and the absorbance was measured at $570 \mathrm{~nm}$ after cells were kept in the dark overnight.

\subsection{RBL-2H3 Cell Line Assay}

RBL-2H3 cells are the tumor analog of mast cells, which after being sensitized with mouse monoclonal IgE or ionophore A23187 respond by releasing inflammatory mediators such as $\beta$-hexosaminidase [11]. As a result, the sample is considered to have anti-allergic activity if it can inhibit mast cells degranulation and produce a significant reduction in $\beta$-hexosaminidase release. Firstly, we performed a cell viability assay (using MTT) to ensure that the activity of the sample at the used concentration was related to the inhibition of histamine release rather than to the cytotoxicity of the RBL-2H3 cells. The cell viability assay was done as follows: RBL-2H3 cells (100 $\mu \mathrm{L}, 1 \times 10^{5}$ cells/well) were cultured with EMEM in a 96-well plate for $24 \mathrm{~h}$. Then samples $(1 \mu \mathrm{L} /$ well; DMSO $1 \mu \mathrm{L}$ as control) were added. After $24 \mathrm{~h}$ incubation in a $\mathrm{CO}_{2}$ incubator at $37^{\circ} \mathrm{C}$, MTT ( $10 \mu \mathrm{L}, 5 \mathrm{mg} / \mathrm{mL}$ in PBS) was added to each well, and the plate was incubated for another $4 \mathrm{~h}$. The medium was then removed, acid iso-propanol $(100 \mu \mathrm{L}$, containing $0.04 \mathrm{~N} \mathrm{HCl})$ reagent was added to each well, the plate was incubated overnight at room temperature, and the absorbance was read at $570 \mathrm{~nm}$ using a microplate reader.

The anti-allergy assay was determined as previously described [12] with minor modification, as follows: RBL-2H3 cells $\left(1 \times 10^{6}\right.$ cells/well $)$ were inoculated with EMEM in a 96-well plate for $48 \mathrm{~h}$, then EMEM medium was replaced by tyroid buffer $\left[100 \mu \mathrm{L}, 130 \mathrm{mM} \mathrm{NaCl}, 5 \mathrm{mM} \mathrm{KCl}, 1.4 \mathrm{mM} \mathrm{CaCl}, 1 \mathrm{mM} \mathrm{MgCl}{ }_{2} \cdot 6 \mathrm{H}_{2} \mathrm{O}, 10\right.$ mM HEPES (4-(2-hydroxyethyl)-1-piperazineethanesulfonic acid), $5.6 \mathrm{mM}$ glucose, 0.1\% BSA, pH 7.2/well], sample $\left(1 \mu \mathrm{L} /\right.$ well) was added, and the plate was incubated for $30 \mathrm{~min}$ in $\mathrm{CO}_{2}$ incubator at $37^{\circ} \mathrm{C}$. A23187 (10 $\mu \mathrm{g} / \mathrm{mL}, 2 \mu \mathrm{L} /$ well) was added after removal of the sample and the addition of new tyroid buffer $(100 \mu \mathrm{L} /$ well $)$. After 30 min incubation, $50 \mu \mathrm{L}$ from each well was collected and transferred to another 96-well plate. An equal volume of substrate solution (l mM), $p$-nitrophenyl- $N$-acetyl- $\beta$-glucosaminide was added to each well, and the plate was left at room temperature on the shaker for $1 \mathrm{~h}$. Finally, the reaction was terminated by adding $100 \mu \mathrm{L}$ of stopping buffer $\left(\mathrm{Na}_{2} \mathrm{CO}_{3}, 100 \mathrm{mM}, \mathrm{pH}=10\right)$, and the absorbance was measured at $405 \mathrm{~nm}$ using a microplate reader. The statistical difference between the control and each sample was determined by student's t-test.

\subsection{Antibacterial Assay}

This assay was determined as described previously [13] with little modification. Briefly, a single colony of the test strain (Escherichia coli and Staphylococcus aureus) was taken and added to $5 \mathrm{~mL}$ of NB medium. This medium was incubated at $37^{\circ} \mathrm{C} \pm 1^{\circ} \mathrm{C}, 120 \mathrm{rpm}$ for $20 \mathrm{~h}$. It was then added to bacterial suspension to prepare a bacterial concentration at $10^{5} \mathrm{CFU} / \mathrm{mL}$. The bacterial solution was used for the following antibacterial assay. In each well of a 96-well plate, $133.5 \mu \mathrm{L}$ of NB medium, $15 \mu \mathrm{L}$ of bacteria suspension, and 1.5 $\mu \mathrm{L}$ of DMSO were added with or without each sample. Also, sorbic acid $(400 \mu \mathrm{g} / \mathrm{mL})$ was used as a positive control. The plate was incubated at $37^{\circ} \mathrm{C} \pm 1^{\circ} \mathrm{C}, 1160 \mathrm{rpm}$ for $18 \mathrm{~h}$. Finally, bacterial growth was measured by a micro-plate reader $(630 \mathrm{~nm})$. The statistical difference between the control and each sample was determined by student's t-test. The MIC (minimum inhibitory concentration) was the lowest concentration of the test extract that completely prevented growth until $18 \mathrm{~h}$.

Also the activity of citric acid was tested against Propionibacterium acnes using the same procedure as above except the use of GAM broth instead of $\mathrm{N}$. broth, bacterial concentration at $10^{1} \mathrm{CFU} / \mathrm{mL}$ and finally plate was incubated at $37^{\circ} \mathrm{C} \pm 1^{\circ} \mathrm{C}, 1160 \mathrm{rpm}$ for $24 \mathrm{~h}$. Also benzalkonoium chloride was used as positive control in case of P. acne.

\subsection{Hyaluronic Acid (HA) ELISA Assay}

Scientific studies have shown that HA improves skin hydration, stimulates production of collagen in skin, works as an antioxidant and free radical scavenger, maintains skin elasticity, cushions joints and nerve tissues, has an 
antibacterial and anti-inflammatory activity and maintains the fluid in the eye tissues, which may help to protect against numerous possible eye concerns [14].

Citric acid was tested for the effect of the production of HA by the use of HA ELISA assay using Biotech Trading Partners (Encinitas, California) according to manufacture's instruction.

This kit is an enzyme-linked binding protein assay that uses a capture molecule known as hyaluronic acid binding protein (HABP). After growing of the fibroblast cells, they are incubated in HABP-coated micro well plate. Properly samples and HA reference solution are added to this plate, allowing HA present to react with the immobilized binding protein. After removal of unbound molecules by washing, HABP conjugated with horseradish peroxidase (HRP) solution is added to the microwells to form complexes with bound HA. Following another washing step, a chromogenic substrate of tetramethylbenzidine and hydrogen peroxide is added to develop a colored reaction. The intensity of the color is measured in optical density units with a spectrophotometer at 450 $\mathrm{nm}$. The higher the intensity of the color, the higher ability of the sample to produce hyaluronic acid.

\section{Results and Discussion}

\subsection{Biotransformation}

\subsubsection{Effect of Time}

Table 2 shows the time course of citric acid production from corncobs, it was concluded that A. niger ATCC 10549 produces the highest amount of citric acid on $8^{\text {th }}$ day.

\subsubsection{Effect of Temperature and $\mathrm{pH}$}

As shown in Table 3 and Table 4, temperature and $\mathrm{pH}$ were found to have a profound influence on fungal production of citric acid from corncobs. A. niger ATCC 10549 produce the highest amount of citric acid at $30^{\circ} \mathrm{C}$ and $\mathrm{pH} 3$.

\subsubsection{Effect of Substrate Concentration}

The effect of substrate concentration on citric acid production was illustrated in Table 5. As corncobs concentration was increased from 6\% to 24\%, the yield of citric acid by A. niger ATCC 10549 was increased from 56.6 to $459.6 \mu \mathrm{g} / \mathrm{mL}$. Corncobs concentration above this value decreases the yield of citric acid. The reduction of

Table 2. Production of citric acid from corncobs using A. niger ATCC 10549.

\begin{tabular}{cc}
\hline Time & Concentration $(\boldsymbol{\mu g} / \mathbf{m L})($ mean $\pm \mathbf{S D}, \mathbf{n}=\mathbf{2})$ \\
\hline 6 days & $263.5 \pm 5.93$ \\
8 days & $295.0 \pm 3.81$ \\
10 days & $273.5 \pm 2.17$ \\
12 days & $243.5 \pm 2.17$ \\
14 days & $195.8 \pm 2.12$ \\
16 days & $113.5 \pm 5.44$ \\
\hline
\end{tabular}

Table 3. Result of the effect of temperature on citric acid production.

\begin{tabular}{cc}
\hline Temperature ${ }^{\circ} \mathbf{C}$ & Concentration $(\boldsymbol{\mu g} / \mathbf{m L})(\mathbf{m e a n} \pm \mathbf{S D}, \mathbf{n}=\mathbf{2})$ \\
\hline 5 & $101.2 \pm 39.17$ \\
15 & $135.8 \pm 8.76$ \\
24 & $221.2 \pm 50.06$ \\
30 & $443.5 \pm 6.50$ \\
37 & $284.3 \pm 27.22$ \\
42 & $92.7 \pm 16.33$ \\
\hline
\end{tabular}


Table 4. Result of different initial pH values on citric acid production.

\begin{tabular}{cc}
\hline $\mathbf{p H}$ value & Concentration $(\boldsymbol{\mu g} / \mathbf{m L})(\mathbf{m e a n} \pm \mathbf{S D}, \mathbf{n}=\mathbf{2})$ \\
\hline 3 & $458.2 \pm 6.50$ \\
5 & $270.5 \pm 88.65$ \\
5.5 & $302.0 \pm 1.62$ \\
6 & $275.0 \pm 3.30$ \\
6.5 & $272.0 \pm 12.42$ \\
7 & $382.0 \pm 55.48$ \\
8 & $342.7 \pm 39.16$ \\
\hline
\end{tabular}

Table 5. Result of the effect of corncobs concentration in the culture filtrate on citric acid production.

\begin{tabular}{cc}
\hline Concentration of corncob in water $(\%, \mathbf{w} / \mathbf{v})$ & Concentration of citric acid $(\boldsymbol{\mu g} / \mathbf{m L})(\mathbf{m e a n} \pm \mathbf{S D}, \mathbf{n}=\mathbf{2})$ \\
\hline 6 & $56.6 \pm 8.65$ \\
12 & $176.61 \pm 40.24$ \\
24 & $327.3 \pm 3.26$ \\
30 & $459.6 \pm 2.17$ \\
40 & $137.3 \pm 14.14$ \\
60 & $143.5 \pm 19.57$ \\
\hline
\end{tabular}

citric acid yield at high substrate concentration could be due to decrease in water content in the medium as has been observed for sucrose hydrolysis at very high concentration by yeast beta-fructofuranosidase.

\subsection{B16 Melenoma Cell Line Assay}

An important concept when selecting bioactive compounds that modulates skin pigmentation that for obvious reasons, they should have minimal effects on cell proliferation and/or toxicity. Taking into consideration about the cytotoxicity to cell lines, the most active concentration of citric acid exhibiting melanin synthesis inhibition $(\sim 33 \%)$ and at the same time with moderate cytotoxicity (16\%) was $200 \mu \mathrm{g} / \mathrm{mL}$, followed by concentration 100 $\mu \mathrm{g} / \mathrm{mL}$ (20\% inhibition) with low cytotoxicity (10\% cytotoxicity). Citric acids at concentrations of lower than $100 \mu \mathrm{g} / \mathrm{mL}$ have no melanin inhibition effect. Results are shown in Figure 1.

\subsection{RBL-2H3 Cell Line Assay}

The highest inhibition of $\beta$-hexosaminidase release was recorded at both concentration of $1000 \mu \mathrm{g} / \mathrm{mL}$ and 500 $\mu \mathrm{g} / \mathrm{mL}$ (82\% in A23187 assay). However, citric acid showed high toxicity (75\%) at $1000 \mu \mathrm{g} / \mathrm{mL}$ compared to those at $500 \mu \mathrm{g} / \mathrm{mL}$ which showed lower cytotoxicity (29\%). Citric acid at $250 \mu \mathrm{g} / \mathrm{mL}$ showed $45 \%$ inhibition of $\beta$-hexosaminidase release without cytotoxicity. Results are shown in Figure 2.

\subsection{Antibacterial Assay}

From the results, it was shown that citric acid completely inhibit the growth of $S$. aureus, E. coli and $P$. acne with MIC = 25, 50 and $200 \mu \mathrm{g} / \mathrm{mL}$, respectively. Results are shown in Figure 3.

\subsection{Hyaluronic Acid (HA) Production Assay in Fibroblast}

It was found that citric acid at both tested concentration have a very good stimulating effect for the production of hyaluronic acid more than $N$-acetyl glucosamine (NAcG) which is used as positive control and at the same time they showed no cytotoxic to the cell. Results are shown in Figure 4. 


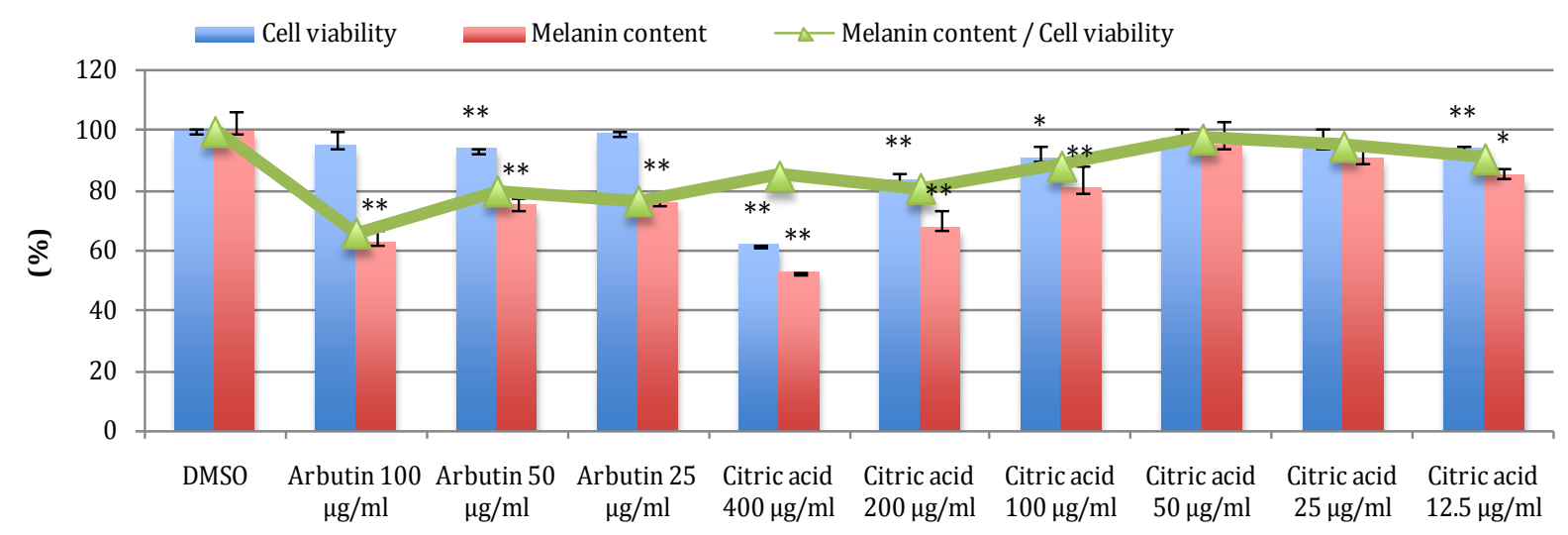

Figure 1. Effect of citric acid on melanin formation in B16 melenoma cell. The values are represented as the mean \pm standard deviation (SD), $\mathrm{n}=3$. Significant difference from the control value and each compound was determined by student's t-test: ${ }^{*} P<0.05,{ }^{* *} P<0.01$.

Cell viability $\quad \square \beta$-Hexosaminidase (A23187)

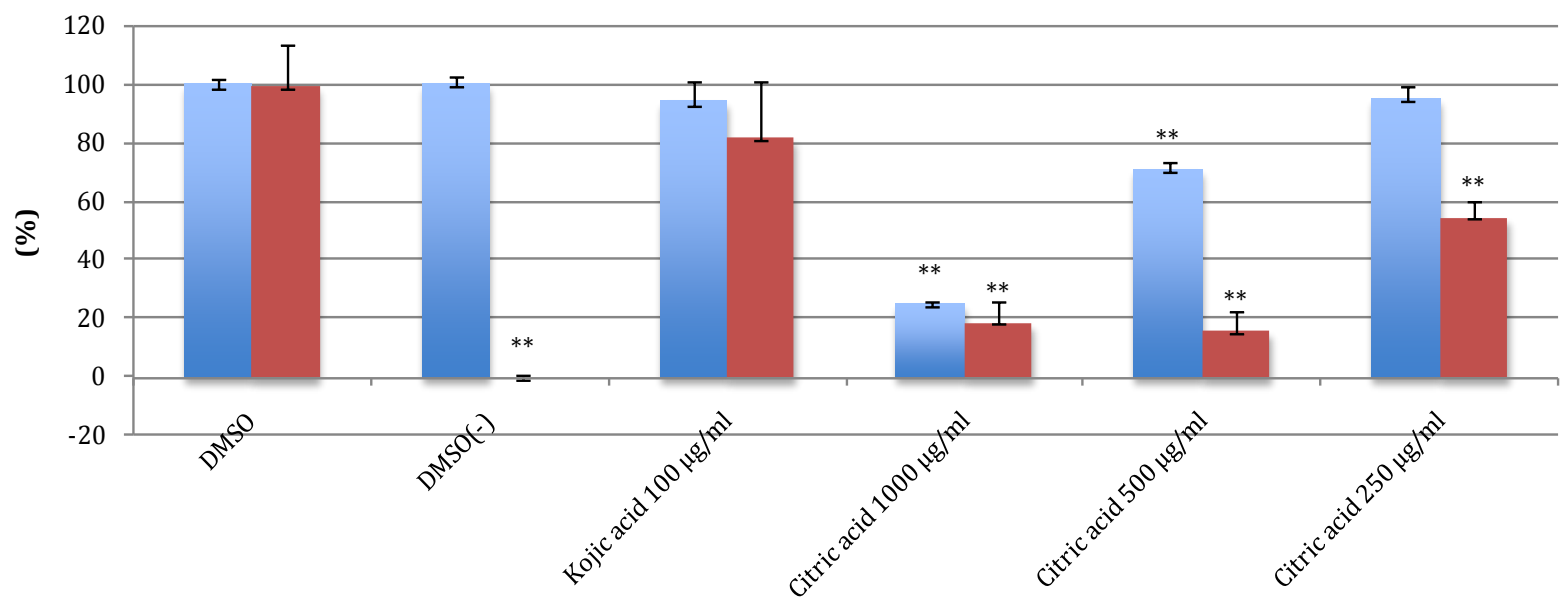

Figure 2. Cell viability and effects of various citric acid concentrations on ionophore A23187-stimulated $\beta$-hexosaminidase release from RBL-2H3 basophilic leukemia cells, DMSO group represent the wells with addition of A23187. DMSO (-) represent the wells without addition of A23187. All the values are the mean \pm SD $(n=5)$. *Significant difference from the control group $(P<0.01)$.

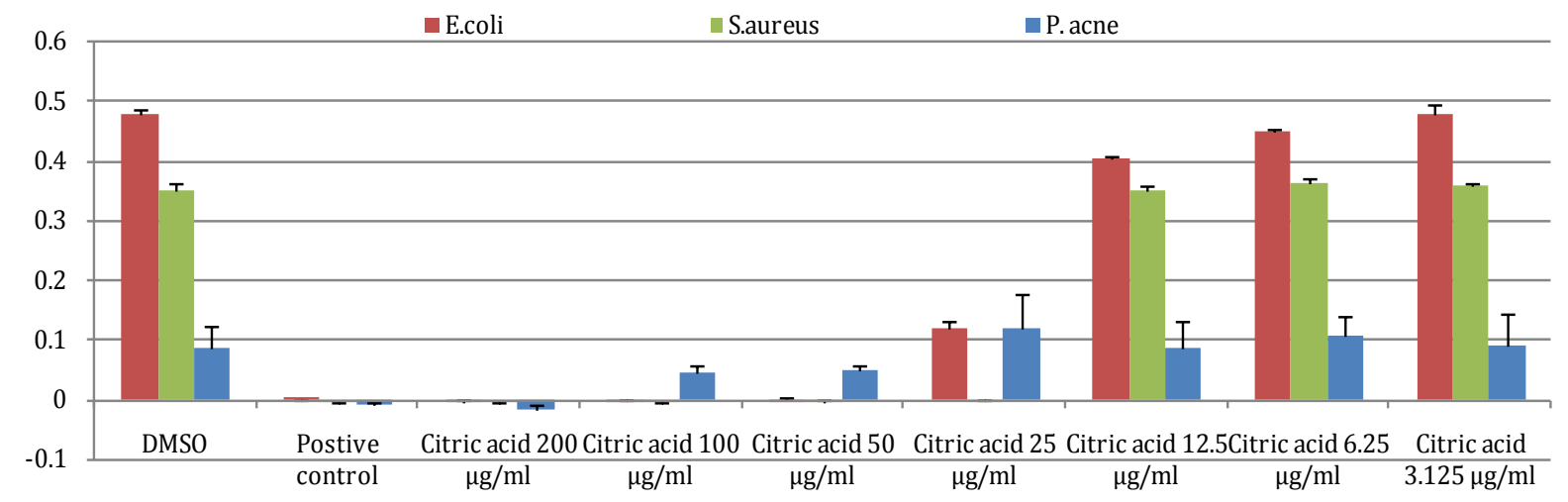

Figure 3. Anti-bacterial activity against E. coli, S. aureus and P. acne. The values are represented as the mean \pm standard deviation (SD), $\mathrm{n}=3$. Final concentrations; $400 \mu \mathrm{g} / \mathrm{mL}$ for sorbic acid (E. coli, $S$. aureus) and benzalkonium chloride $(P$. acne). Significant difference between $1 \%$ DMSO and each concentration was determined by student's t-test: ${ }^{*} P<0.05$, ${ }^{* *} P<$ 0.01 . 


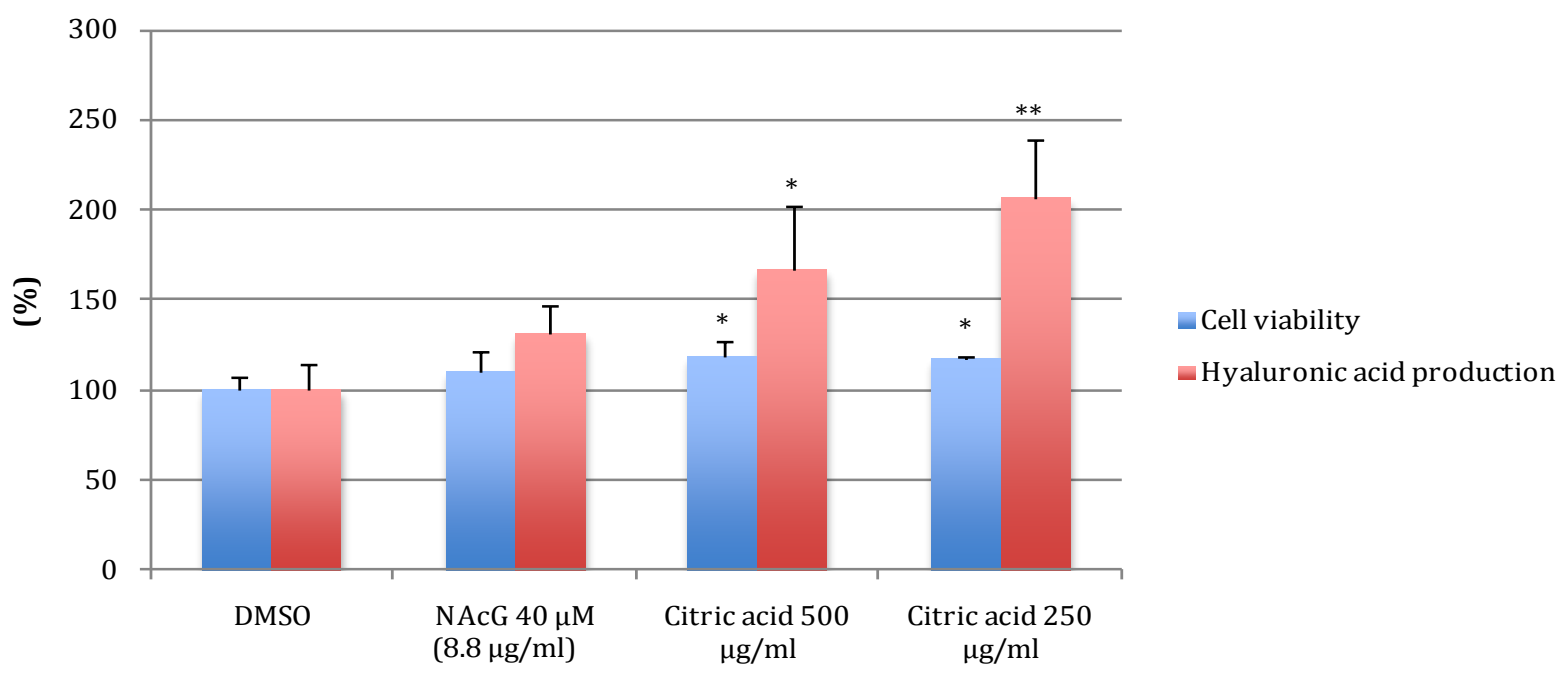

Figure 4. Effect of citric acid on the production of hyaluronic acid. The values are represented as the mean \pm standard deviation (SD), $\mathrm{n}=3$. Significant difference between $1 \%$ DMSO and each concentration was determined by student's t-test: ${ }^{*} P<$ $0.05,{ }^{* *} P<0.01$.

\section{Conclusions}

The present work investigates the feasibility of using corncobs as substrates for production of citric acid.

Under the optimal conditions, the fermenting organism was capable of producing $48.4 \mathrm{~g}$ citric acid per kg dry matter of corncobs after 8 days of fermentation. The biological experiment for citric acid indicated that citric acid has interesting biological activities. Previous results showed that the most common use of citric acid as a preservative for its antibacterial effect. However in this study other important biological activities such as melanin inhibition activity, anti-allergy activity and stimulation of hyaluronic acid production were done here for the first time. To the best of our knowledge that citric acid was proved to have interesting result in these biological experiments.

\section{References}

[1] Diomi, M., Elisavet, K. and Paul, C. (2008) Fungal Multienzyme Production on Industrial By-Products of the CitrusProcessing Industry. Bioresource Technology, 99, 2373-2383. http://dx.doi.org/10.1016/j.biortech.2007.05.018

[2] Inglett, G.E. (1970) Corn: Culture, Processing and Products. AVI Publishing Co., Waetport.

[3] Barl, B., Biliaderis, C., Murray, E. and MacGregor, A. (1991) Combined Chemical and Enzymic Treatments of Corn Husk Lignocellulosics. Journal of Science of Food Agriculture, 56, 195-214. http://dx.doi.org/10.1002/jsfa.2740560209

[4] Prescott, S.C. and Dunn, C.G. (1982) Citric Acid. In: Industrial Microbiology, 4th Edition, AVI Pub. Co. INC., Westport, 709-747.

[5] Kapoor, K., Chaudhary, K. and Tauro, P. (1982) Citric Acid. In: Reed, G., Ed., Precott and Dunn's Industrial Microbiology, 4th Edition, The AVI Publishing Co., Westport.

[6] Hang, Y. and Woodams, E. (1998) Production of Citric Acid from Corncobs by Aspergillus niger. Bioresource Technology, 65, 251-253. http://dx.doi.org/10.1016/S0960-8524(98)00015-7

[7] Doelle, H.W., Mitchell, D.R. and Rolz, C.E. (1992) Solid Substrate Cultivation. Elsevier Applied Science, London, 7-16.

[8] Sankpal, N.V., Joshi, A.P. and Kulkarni, B.D. (2001) Citric Acid Production by Aspergillus niger Immobilized on Cellulose Microfibrils: Influence of Morphology and Fermenter Conditions on Productivity. Process Biochemistry, 36, 1129-1139. http://dx.doi.org/10.1016/S0032-9592(01)00155-8

[9] Marier, J. and Boulet, M. (1958) Direct Determination of Citric Acid in Milk with an Improved Pyridine-Acetic Anhydride Method. Journal of Dairy Science, 41, 1683. http://dx.doi.org/10.3168/jds.S0022-0302(58)91152-4

[10] Arung, E., Shimizu, K. and Kondo, R. (2007) Structure-Activity Relationship of Prenyl-Substituted Polyphenols from Artocarpus heterophyllusas Inhibitors of Melanin Biosynthesis in Cultured Melanoma Cells. Chemistry \& Biodiversity, 
4, 2166-2171. http://dx.doi.org/10.1002/cbdv.200790173

[11] Ikawati, Z., Wahyuono, S. and Maeyama, K. (2001) Screening of Several Indonesian Medicinal Plants for Their Inhibitory Effect on Histamine Release from RBL-2H3 Cells. Journal of Ethnopharmacology, 75, 249-256. http://dx.doi.org/10.1016/S0378-8741(01)00201-X

[12] Yun, S., Kang, M., Park, J. and Nam, S. (2010) Comparison of Anti-Allergenic Activities of Various Polyphenols in Cell Assays. Applied Biological Chemistry, 53, 139-146. http://dx.doi.org/10.3839/jabc.2010.026

[13] Tatli, İ. and Akdemir, Z. (2005) Antimicrobial and Antimalarial Activities of Secondary Metabolites from Some Turkish Verbascum Species. Fabad Journal of Pharmceutical Sciences, 30, 84-92.

[14] Necas, J., Bartosikova, L., Brauner, P. and Kolar J. (2005) Hyaluronic Acid (Hyaluronan): A Review. Veterinarni Medicina, 53, 397-411. 